\title{
Rhipicephalus (Boophilus) microplus resistant to acaricides and ivermectin in cattle farms of Mexico
}

Rhipicephalus (Boophilus) microplus resistentes aos acaricidas e ivermectina nas fazendas de gado do México

Róger Iván Rodríguez-Vivas ${ }^{1 *}$; Luis Carlos Pérez-Cogollo; ;osé Alberto Rosado-Aguilar ${ }^{1}$;

Melina Maribel Ojeda-Chi ${ }^{1}$; Iris Trinidad-Martinez ${ }^{1}$; Robert John Miller²; Andrew Yongsheng Lí ${ }^{3}$; Adalberto Pérez de León ${ }^{3}$; Félix Guerrero ${ }^{3}$; Guilherme Klafke ${ }^{4}$

${ }^{1}$ Facultad de Medicina Veterinaria y Zootecnia, Universidad Autónoma de Yucatán, Mérida, Yucatán, México

${ }^{2}$ Cattle Fever Tick Research Laboratory, USDA, Edinburg, USA

${ }^{3}$ Knipling-Bushland U.S. Livestock Insects Research Laboratory, USDA, ARS, Kerrville, USA

${ }^{4}$ FEPAGRO Saúde Animal. Laboratório de Parasitologia, Eldorado do Sul, RS, Brasil

Received October 16, 2013

Accepted February 17, 2014

\begin{abstract}
Ticks and the diseases they transmit cause great economic losses to livestock in tropical countries. Non-chemical control alternatives include the use of resistant cattle breeds, biological control and vaccines. However, the most widely used method is the application of different chemical classes of acaricides and macrocyclic lactones. Populations of the cattle tick, Rhipicephalus (Boophilus) microplus, resistant to organophosphates (OP), synthetic pyrethroids (SP), amitraz and fipronil have been reported in Mexico. Macrocyclic lactones are the most sold antiparasitic drug in the Mexican veterinary market. Ivermectin-resistant populations of $R$. (B.) microplus have been reported in Brazil, Uruguay and especially in Mexico (Veracruz and Yucatan). Although ivermectin resistance levels in $R$. (B.) microplus from Mexico were generally low in most cases, some field populations of $R$. (B.) microplus exhibited high levels of ivermectin resistance. The CHPAT population showed a resistance ratio of 10.23 and 79.6 at lethal concentration of $50 \%$ and $99 \%$, respectively. Many field populations of $R$. (B.) microplus are resistant to multiple classes of antiparasitic drugs, including organophosphates (chlorpyrifos, coumaphos and diazinon), pyrethroids (flumethrin, deltamethrin and cypermethrin), amitraz and ivermectin. This paper reports the current status of the resistance of $R$. (B.) microplus to acaricides, especially ivermectin, in Mexican cattle.
\end{abstract}

Keywords: Rhipicephalus (B.) microplus, acaricide, resistance, macrocyclic lactone, tick control.

\section{Resumo}

Carrapatos e as doenças por eles transmitidas causam grandes perdas econômicas ao gado dos países tropicais. Alternativas não-químicas incluem o uso de raças de gado que sejam resistentes, controle biológico e vacinas. No entanto, o método mais utilizado é a aplicação de diferentes classes químicas de acaricidas e lactonas macrocíclicas. Populações de piolhos de gado, Rhipicephalus (Boophilus) microplus, resistentes aos organofosfatos (OP), piretoides sintéticos (SP), amitraz e fipronil, foram descritas no México. Lactonas macrocíclicas são as drogas antiparasitárias mais vendidas no mercado veterinário mexicano. Populaçôes de $R$. (B.) microplus resistentes à irvemectina foram relatadas no Brasil, Uruguai e especialmente no México (Veracruz e Yucatan). Embora os níveis de resistência à ivermectina no $R$. (B.) microplus do México tenha sido relativamente baixa, na maioria dos casos, algumas populaçóes campestres de $R$. (B.) microplus mostraram altos níveis de resistência à ivermectina. A população CHPAT mostrou uma razão de resistência de 10,23 e 79,6 na concentração letal de 50\% e 99\%, respectivamente. Muitas populaçôes campestres de $R$. (B.) microplus são resistentes a múltiplas classes de drogas antiparasitárias, incluindo organofosfatos (clorpirifós, coumafos e diazinon), piretoides (flumetrina, deltametrina e cipermetrina), amitraz e ivermectina. Este artigo relata o estado atual de resistência do $R$. (B.) microplus aos acaricidas, especialmente ivermectina, no gado mexicano.

Palavras-chave: Rhipicephalus (B.) microplus, acaricida, resistência, lactona macrocíclica, controle de carrapatos.

\footnotetext{
*Corresponding author: Róger Iván Rodríguez-Vivas

Facultad de Medicina Veterinaria y Zootecnia, Universidad Autónoma de Yucatán,

Km 15.5 carretera Mérida-Xmatkuil, CP. 97100, Mérida, Yucatán, México

e-mail: rvivas@uady.mx
} 


\section{Introduction}

Rhipicephalus (Boophilus) microplus (R. (B.) microplus) (Canestrini) is an endemic pest of cattle in tropical and subtropical regions of the world, causing major economic losses to cattle producers through direct physical effects on the parasitized animal and indirectly through transmission of infectious disease agents such as Babesia bovis, B. bigemina and Anaplasma marginale (SOLORIO-RIVERA et al., 1999; RODRÍGUEZ-VIVAS et al., 2004, 2005).

Chemical acaricides have played an essential role in control of this tick, but intensive acaricide use has favored the development of resistant populations (RODRÍGUEZ-VIVAS et al., 2006a, b). Macrocyclic lactones (MLs) have emerged as an alternative to mitigate the negative effects of ticks, including tick populations resistant to most acaricides (LANUSSE et al., 1997). Macrocyclic lactones are endectocides derived from Streptomyces avermitilis (avermectins) S. cyaneogriseus (milbemicins) and the genus Saccharopolyspora (Spinosyns) (LIFSCHITZ et al., 2002; LUMARET et al., 2012). In Mexico, the pharmaceutical industry reported that ivermectin is the preferred anthelmintic to control gastrointestinal nematodes in ruminants and it is also used to control cattle ticks (RODRÍGUEZVIVAS et al., 2014). However, as an effect from its intensive use, reports of $R$. (B.) microplus resistant to ivermectin have been documented in Brazil, Uruguay and Mexico (KLAFKE et al., 2006; CASTRO-JANER et al., 2011; PEREZ-COGOLLO et al., 2010a, b; FERNÁNDEZ-SALAS et al., 2012a, b). This paper reports the current status of the resistance of $R$. (B.) microplus to acaricides, especially ivermectin, in Mexican cattle.

\section{Effect of Rhipicephalus (B.) microplus on Cattle Production}

Approximately one billion cattle, most of which are in the tropics, are at risk from various tick species or tick-borne diseases (PEGRAM et al., 1993), causing significant production losses. Rhipicephalus (B.) microplus is an endemic pest of cattle in tropical and subtropical regions of the world, causing major economic losses to cattle producers through direct physical effects on the parasitized animal and indirectly through disease transmission of infectious agents such as Babesia bovis, B. bigemina and Anaplasma marginale (SOLORIO-RIVERA et al., 1999; RODRÍGUEZVIVAS et al., 2004, 2005). In addition to the costs of chemicals, labor, equipment and production losses associated with treatment, the cost of maintaining tick-free zones and boundaries is highly expensive (WHITE et al., 2003).

Each engorged female tick has been shown to reduce weight gain by $0.6 \mathrm{~g}$ in beef cattle (SUTHERST et al., 1983) of which $65 \%$ was attributed to tick infestation (stress and anorexia from the irritation cause by the ticks) and $35 \%$ to loss of blood taken by the ticks (SEEBECK et al., 1971). In Australia, Jonsson et al. (1998) estimated that each engorging female of $R$. (B.) microplus was responsible for the loss of $8.9 \mathrm{ml}$ of daily milk production and $1.0 \mathrm{~g}$ of bodyweight.. In the last study reported in Mexico, the estimated cost of production losses, mortality, hide damage and control of $R$. (B.) microplus and its transmitted diseases was estimated to be $\$ 48$ million USD per annum (RODRÍGUEZVIVAS et al., 2005).

Current tick-control methods involve use of non-chemical and chemical methods, and the systematic application of two or more methods (integrated pest management). Chemical control is the most widely used and in most cases the only method available to the producer (RODRÍGUEZ-VIVAS et al., 2006a). The present work will focus on chemical control of ticks.

\section{Chemical Control of Rhipicephalus (B.) microplus}

Available chemicals used in the treatment of ectoparasites of veterinary importance act either systemically, following uptake of the compound from host tissues, or by direct contact with the target parasites following external application. Virtually all ectoparasiticides are neurotoxins, exerting their effect on the ectoparasite nervous system (TAYLOR, 2001) (Table 1). Traditional methods for the delivery of an acaricide treatment to cattle to control ticks required formulations such as an emulsifiable concentrate, wettable powder or flowable products that could be diluted in water and applied to cattle by a hand sprayer, spray race or through immersion of animals in a dipping vat. More recently, treatment possibilities include the use of pour-on products, injectables, an intraruminal bolus, acaricide-impregnated ear tag and pheromoneacaricide-impregnated devices attached in different ways to the host (GEORGE et al., 2004).

Many drug classes have been and are used as acaricides to treat cattle ticks, this include arsenicals, organochlorides (OCs), organophosphates (OPs), carbamates, amidines, phenylpyrazoles, insect growth regulators, synthetic pyrethroids (SPs) and MLs (AGUILAR-TIPACAMU; RODRIGUEZ-VIVAS, 2003; GEORGE et al., 2004).

In Mexico, organophosphate acaricides were heavily used in the national tick eradication program between 1974 and 1984 (TRAPAPA, 1989). The organophosphates used during that period include coumaphos, chlorpyriphos, chlorfenvinphos, diazinon and ethion. Pyrethroid and amitraz acaricides were introduced into Mexico in 1986; however, amitraz use was limited initially due to higher cost. The use of amitraz became more frequent after 1993 when SP resistance problems started to hinder the tick control efforts in Mexico. One chemical alternative for the control of ticks in Mexico is the use of MLs that exhibit an endectocidal spectrum of activity including acaricidal properties (RODRÍGUEZ-VIVAS et al., 2010)

\section{Currently Major Used Acaricide Groups}

Organophosphates and Carbamates. Organophosphates, i.e. coumaphos, and carbamates have similar effect acting on acetylcholinesterase (AChE) (CORBETT, 1974a, b). AChE is one of the most efficient enzymes, being capable of an extremely rapid rate of hydrolysis of acetylcholine and generation of the active enzyme (KWONG, 2002). Organophosphates are neutral esters 
Table 1. Mode of action and target sites for currently used acaricides and macrocyclic lactones.

\begin{tabular}{|c|c|c|c|}
\hline Antiparasitic drug & Site of action & Mode of action & References \\
\hline \multicolumn{4}{|l|}{ Acaricides } \\
\hline Organophosphates & Acetylcholinesterase & $\begin{array}{l}\text { Inhibiting the action of acetylcholinesterase at cholinergic } \\
\text { synapses and at muscle end plates. }\end{array}$ & MacDonald (1995) \\
\hline Pyrethroids & Voltage-gated $\mathrm{Na}+$-channel & $\begin{array}{l}\text { Prolonged opening of sodium channels in nerve, muscle } \\
\text { and other excitable cells. }\end{array}$ & Catterall (2001) \\
\hline Phenylpyrazoles & GABA receptor & $\begin{array}{l}\text { Blocking transmission of signals by the inhibitory neu- } \\
\text { rotransmitter, GABA. The compound binds within the } \\
\text { chloride channel and consequently inhibits the flux of } \mathrm{Cl}^{-} \\
\text {ions into the nerve cell. }\end{array}$ & Cole et al. (1993) \\
\hline Benzoylphenyl urea & Chitin formation & Chitin synthesis inhibitors. & Spindler et al. (1990) \\
\hline Formamidines & Octopamine receptors & Agonism of octopamine receptors. & Evans and Gee (1980) \\
\hline \multicolumn{4}{|l|}{ Macrocyclic lactones } \\
\hline Avermectins & Glutamate-gated $\mathrm{Cl}^{-}$-channel & $\begin{array}{l}\text { Blocking nerve signals by interfering with the glutamate- } \\
\text { gated chlorid }(\mathrm{GluCl}) \text { channel receptors }\end{array}$ & Martin et al. (2002) \\
\hline Milbemycins & Glutamate-gated $\mathrm{Cl}^{-}$-channel & $\begin{array}{l}\text { High affinity for the glutamate-gated ion channels in close } \\
\text { proximity to GABA-gated chloride channels. }\end{array}$ & Lumaret et al. (2012) \\
\hline \multirow[t]{2}{*}{ Spinosyns } & $\begin{array}{l}\text { Nicotinic acetylcholine recep- } \\
\text { tors }\end{array}$ & Disruption of nicotinic acetylcholine receptors. & Lewer et al. (2009) \\
\hline & & Spinosyn A may has a novel mode of action. & Orr et al. (2009) \\
\hline
\end{tabular}

of phosphoric acid or its thio analogue and act by inhibiting the action of AChE at cholinergic synapses and at muscle end plates. The OP mimics the structure of acetylcholine (Ach) and when it binds to AChE it causes transphosphorylation of the enzyme. The transphosphorylated $\mathrm{AChE}$ is unable to breakdown accumulating Ach at the post-synaptic membrane leading to neuromuscular paralysis (TAYLOR, 2001). Organophosphate compounds can be extremely toxic in animals and humans causing an inhibition of AChE. They are generally active against fly larvae, flies, lice, ticks and mites on domestic livestock and fleas and ticks on dogs and cats, although activity varies between compounds and differing formulations (MacDONALD, 1995).

Synthetic pyrethroids. The term "pyrethroid" is commonly used to designate a synthetic insecticide that is derived structurally from the natural pyrethrins. Pyrethroids are grouped into two categories (type I and type II) based on their distinct poisoning symptoms, effects on nerve preparations, and their chemical structures (NARAHASHI, 1986). Type I pyrethroids lack an $\alpha$-cyano group which is present at the phenylbenzyl alcohol position of type II pyrethroids. Type I pyrethroids cause repetitive discharges in response to a single stimulus, while type II pyrethroids cause a membrane depolarization accompanied by a suppression of the action potential (SODERLUND et al., 2002). The mode of action of pyrethroids has been studied using vertebrate and non-insect invertebrate nerve preparations. Collectively, these studies show that pyrethroids cause prolonged opening of sodium channels in nerve, muscle and other excitable cells (CATTERALL, 2001), primarily by inhibiting channel deactivation and stabilizing the open configuration of the sodium channel (CATTERALL, 2001; SODERLUND et al., 2002; RAYMOND-DELPECH et al., 2005). Studies on the mechanism of action of pyrethroids on insect sodium channels expressed in oocytes and the molecular mechanism of knockdown resistance $(k d r)$ confirmed that sodium channels are the target of SP insecticides (DONG, 2007). Type I pyrethroids (i.e. cismethrin and permethrin) appear to bind to resting or inactivated channels, shifting the voltage dependence of activation to more negative potentials and causing a slowlyactivating sodium current. These compounds also produce characteristic sodium tail currents following a depolarizing pulse that decay with first-order time constants (ZHAO et al., 2000). In contrast to these results, Type II pyrethroids exhibit profound use-dependent modification of sodium currents, which implies that these compounds bind preferentially to activate sodium channel states (TAN et al., 2002). The lethal activity of SP seems to involve action on both peripheral and central neurones, while the knock-down effect, is probably produced by peripheral neuronal effects only (CASIDA et al., 1983).

Cypermethrin, deltamethrin and cyhalothrin are examples of SPs that are effective on susceptible ticks (> 98\% of efficacy). Flumethrin was designed for application to cattle as pour-on, but there is also an emulsifiable concentrate formulation that can be applied as a dip or spray. The active ingredient in the pour-on has a remarkable capacity for spreading rapidly on the skin and hair from points of application along the dorsal line of an animal to all areas of the body. The residual effect of treatment with flumethrin is extended if the pour-on formulation is applied (GEORGE et al., 2004). Flumethrin for the control of both one-host and multi-host ticks species on cattle is effective at relatively low concentrations compared to other SPs (STENDEL, 1985).

Phenylpyrazoles. Fipronil is a phenylpyrazole compound, which blocks transmission of signals by the inhibitory neurotransmitter, GABA, presents in insects (RAUH et al., 1990). Fipronil binds within the chloride channel and consequently inhibits the flux of $\mathrm{Cl}$ - ions into the nerve cell resulting in hyperexcitation of the insect nervous system (COLE et al., 1993). Additionally, fipronil and its metabolite fipronil sulfone block two types of glutamate activated 
chloride channels in insects (ZHAO et al., 2005). Also, it acts in the reproductive process by altering both the structure and function of germinative cells of $R$. sanguineus females (OLIVEIRA et al., 2009). Fipronil is used worldwide for the treatment and control of flea and tick infestations on cattle, cats and dogs (TAYLOR, 2001; GEORGE et al., 2004). Fipronil applied as a pour-on to cattle infested with $R$. (B.) microplus had a therapeutic efficacy greater than $99 \%$ in susceptible ticks (DAVEY et al., 1998).

Insect growth regulators. These constitute a group of chemical compounds that do not kill the target parasite directly, but interfere with their growth and development. Insect growth regulators act mainly on immature stages of the parasites and then, are not usually suitable for the rapid control of established adult populations of parasites. Based on their mode of action they can be divided into: a) chitin synthesis inhibitors (benzoylphenyl ureas), b) chitin inhibitors (triazine/pyrimidine derivatives) and c) juvenile hormone analogues (TAYLOR, 2001). Fluazuron, a benzoylphenyl urea, is efficacious against ticks and some mite species. The adverse consequences for ticks on cattle treated with a pour-on of this acaricide are the reduction of the fecundity and fertility of engorged females to near zero, and mortality of immature ticks because they unable to moult to the next instar (GEORGE et al., 2004).

Formamidines. The main member of this group is amitraz, which is a formamidine-like acaricide that acts at octopamine receptor sites in ectoparasites resulting in neuronal hyperexcitability and death (EVANS; GEE, 1980). The overstimulation of octopamine synapses in the CNS results in tremors and convulsions in juvenile and adult arthropods. At sublethal levels these compounds influence egg-laying, feeding activity and raise the excitatory state of the arthropod (ORR et al., 1990). It is toxic against mites, lice and ticks in domestic livestock. In cattle, for example, amitraz has been widely used in dips, sprays or pour-on formulations for the control of single-host and multihost tick species (TAYLOR, 2001). Amitraz continues to be one of the most popular acaricides for the control of $R$. (B.) microplus in Australia, southern Africa and Latin America (JONSSON; HOPE, 2007). Amitraz is unstable in dipping vats, but adding sufficient calcium hydroxide or hydrated lime to raise and maintain the $\mathrm{pH}$ of the vats at 12 , insures the stability of the active ingredient (GEORGE et al., 2004).

Mixture of acaricide groups. Several OPs synergize the toxicity to $R$. (B.) microplus of cypermethrin and deltamethrin. The reduction in concentration of a relatively expensive SP used with a relatively cheap OP acting as a synergist provided an efficacious, inexpensive product for the control of OP-resistant tick populations (SCHNITZERLING et al., 1983). In Australia, the product combination of cypermethrin + chlorfenvinphos and deltamethrin + ethion remains on the market (GEORGE et al., 2004). In Brazil, there are a number of different formulations based on mixtures of OPs and SP, for use in dipping vats, aspersion or in pour-on formulations. The most common are formulated with chlorpyriphos and cypermethrin, with or without a synergist (i.e. pyperonylbutoxide). Also, it is common to find in the market associations between two organophosphates (i.e. chlorpyriphos and dichlorvos). Recently it was launched in the Brazilian market a pour-on formulation of fluazuron in association with abamectin (SINDAN, 2013). The use of these mixtures is very popular in Brazil, in a survey conducted among cattle producers of the state of São Paulo, 30.2\% of them reported the use of OPs and SPs mixtures to control cattle ticks (MENDES et al., 2011). In Mexico, mixtures of acaricides are available in the market and cymiazole + cypermethrin is one of the most used (RODRÍGUEZVIVAS et al., 2006a). One value of these mixtures may be their possible use for the control of both ticks and the horn fly.

One reason to research acaricide mixtures and synergized formulations is their potential to control populations of $R$. (B.) microplus resistant to one of the acaricides in the formulation under consideration. In this way, combination products could prolong the useful life of certain classes of acaricides (BARRÉ et al., 2008; RODRÍGUEZ-VIVAS et al., 2013). Knowles (1982) noted that the formamidine pesticides chlordime form and amitraz can act as a synergist of organophosphate, organochlorine, carbamate, and pyrethroid pesticides. Subsequent publications confirmed the synergism between amitraz, and pyrethroids against ticks (LI et al., 2007). Prullage et al. (2011) demonstrated acaricidal synergism between amitraz and fipronil. Recently, RodríguezVivas et al. (2013) found strong synergism with the mixture of cypermethrin + amitraz + pyperonyl butoxide and this mixture was the most effective killing larvae resistant against pyrethroids in vitro (96.7-100\% of larval mortality), and $>95 \%$ control that persisted for 28 days post-treatment against $R$. (B.) microplus infesting cattle under field conditions in the Mexican tropics. Although the mode of action of pyrethroids and formamidines is different, Liu and Plapp (1990) demonstrated that formamidines act as target-site synergists of pyrethroids by modifying binding cooperativity in target tissues of insects.

Although it is a potentially useful tool to combat acaricide resistance, a product based on an acaricide mixture has to be used rationally (RODRÍGUEZ-VIVAS et al., 2013). Such a strategy needs to be part of an integrated tick control program that incorporates other technologies to minimize the economic impact of $R$. (B.) microplus and other ticks affecting cattle in a sustainable manner (RODRÍGUEZ-VIVAS et al., 2005). For example, synergized mixtures of acaricides may also potentiate the effect of anti-tick vaccines among populations of $R$. (B.) microplus that are already resistant to certain pesticides (NARI-HENRIOUD, 2011; KISS et al., 2012). Stewardship of acaricidal combination products is required because it has been demonstrated that some agriculturally damaging insect species can develop resistance to pesticide mixtures (IRAC, 2012). Further studies on the effect of selection pressure of acaricide mixture on the development of resistance in both laboratory and in field populations of $R$. (B.) microplus are needed.

\section{Macrocyclic Lactone Groups}

MLs are broad-spectrum antiparasitic drugs, extensively used in veterinary medicine. They are known as "endectocide" compounds based on their unique activity against external and internal parasites (SHOOP et al., 1995). The avermectins, milbemycins and spinosyns are collectively referred to as MLs which comprise several classes of chemicals derived from cultures of soil micro- 
organisms. Such compounds are extensively and increasingly used in veterinary medicine and agriculture (LUMARET et al., 2012).

Avermectins. Avermectins are macrocyclic fermentation products of Streptomyces avermitilis (later renamed S. avermectinius). Eight naturally occurring novel macrocyclic lactones, namely avermectin A1a/A1b, A2a/A2b, B1a/B1b, B2a/B2b, have been discovered (LUMARET et al., 2012).

Avermectins inhibit the gamma-aminobutyric acid (GABA) neurotransmission at two or more sites in nematodes, blocking interneuronal stimulation of excitatory motoneurons and thus leading to a flaccid paralysis (TURNER; SCHAEFFER, 1989). The drug is believed to block nerve signals by interfering with the glutamate-gated chloride ( $\mathrm{GluCl}$ ) channel receptors (found only in invertebrates), which make them likely to affect membrane stability (MARTIN et al., 2002). In arthropods, the avermectins interfere with the transmission between nervous and muscular cells, because the GABA receptors are located at the neuromuscular junction. In vertebrates, it stimulates the release of GABA in neurons, but as these are usually in the brain and thus protected by the blood/brain barrier, the drug is exceptionally safe for mammals (ÓMURA, 2008). In the mite Tetranychus cinnabarinus, the major resistance mechanism to avermectin B1 was the increasing activities of carboxylesterases and glutathione-S-transferase and the increase of mixed function oxidase of odemethylase activity (LIN et al., 2009).

Ivermectin and abamectin are generally used to control the ecto- and endoparasites (mites and nematodes) of livestock and antifilarial chemotherapy in humans. Ivermectin is the most widely used avermectin. Ivermectin's exceptional effectiveness has led to some negative aspects being identified. The drug is only partially metabolized in the alimentary tract and residual active ingredient can appear intact in the faeces at levels depending on how the drug is formulated and applied. In animal health, injectable and pour-on formulations are particularly long-living and can prove toxic for 2-8 weeks, especially as avermectins are not water soluble but bind tightly to particulate matter. Due to ivermectin's potency, the residues can cause mortality in a diverse range of invertebrates, especially beetles and fly larvae. ML, especially ivermectin is eliminated in high concentrations in the excreta of treated animals, causing negative effects on dung beetle populations (DIERSMANN et al., 2006; SUÁREZ et al., 2009). Adult individuals of a number of coprophagous beetle species (i.e. the genera Aphodius, Copris, Euoniticellus, Onitis and Onthophagus) exhibit low mortality when exposed to ivermectin, but these species also experience substantial reductions in fecundity, larva survival and imago adult emergence rates (HEMPEL et al., 2006; OECD, 2010).

Milbemycins. Moxidectin, the most important milbemycin, is a semisynthetic methoxime derivative of nemadectin, a fermentation product of Streptomyces cyanogriseus subsp. noncyanogenus. Chemically, avermectins differ from each other by chain substitutions on the lactone ring, whilst milbemycins, which are structurally related, differ from the avermectins through the absence of a sugar moiety from the lactone skeleton (ROCK et al., 2002). Milbemycin oxime is used against intestinal nematodes in dogs and cats, against adult heartworm in dogs, and against ectoparasites in companion animals. Milbemectin (a mixture of $\geq 70 \%$ milbemycin A4 and $\leq 30 \%$ milbemycin A3) is an insecticide and acaricide effective against all development stages of mites. In common with other ML, moxidectin displays a high affinity for the glutamate-gated ion channels specific to invertebrates. These glutamate-gated binding sites apparently occur in close proximity to GABA-gated chloride channels, and the macrolide endectocides may increase GABA-gated sites as well (LUMARET et al., 2012).

Spinosyns. Spinosyns are tetracyclic-macrolide compounds produced from the fermentation of soil-dwelling bacterial species in the genus Saccharopolyspora (LEWER et al., 2009). The active ingredient spinosad consists of a mixture of spinosyns A and D (thus its name, spinosAD) (KIRST, 2010). The unique mechanism of action of spinosyns involves the disruption of nicotinic acetylcholine receptors. However, the spinosyn A, the major constituent of the insecticide spinosad, does not interact directly with known binding sites of insect nicotinic receptors. Orr et al. (2009) suggested that spinosyn A exerts its insecticidal actions via a novel mode of action.

\section{Macrocyclic Lactones Used in Mexico to Control Cattle Ticks}

In Mexico, the pharmaceutical industry reported that MLs were the most used anti-parasitic drugs in domestic ruminants from 2007 to 2009 (45-50\% of the total market) (RODRÍGUEZVIVAS et al., 2014). The efficacy of ivermectin, doramectin and moxidectin for the control of $R$. (B.) microplus populations resistant to OPs, amidine and SPs has been demonstrated (SIBSON, 1994; AGUILAR-TIPACAMU; RODRIGUEZ-VIVAS, 2003; DAVEY et al., 2005). In the Mexican tropics, moxidectin (1\%) has been shown to have an efficacy against natural infestation of $R$. (B.) microplus greater than $95 \%, 28$ days after application (AGUILAR-TIPACAMU; RODRÍGUEZ-VIVAS, 2003). ArietaRomán et al. (2010) showed that the long-acting moxidectin-10\% $(1 \mathrm{mg} / \mathrm{kg})$ and ivermectin-3.15\% $(0.63 \mathrm{mg} / \mathrm{kg})$ have an efficacy against natural infection of $R$. (B.) microplus greater than $95 \%$, 70 and 56 days after applications, respectively. In the USA, Davey et al. (2005) reported that spinosad applied topically to cattle using spray formulations proved effective to control cattle tick infestations.

\section{Resistance of Rhipicephalus (B.) microplus to Acaricides}

In Mexico, R. (B.) microplus has developed resistance to all main classes of acaricides in past decades due to intensive use of chemical acaricides (RODRÍGUEZ-VIVAS et al., 2012). Resistance to OP acaricides first developed in the 1980s in Mexico, and resistance to SP emerged in the 1990s. Amitraz was introduced along with SP to control OP-resistant ticks in 1986. Initially, Amitraz was not widely used, owing to its higher cost, but its use became more prevalent and intensive after SP resistance was discovered in 1993 (FRAGOSO-SANCHEZ et al., 2011). The first case of Amitraz resistance in $R$. (B.) microplus from Mexico was confirmed in 2001 at a ranch in the state of Tabasco (SOBERANES et al., 
2002). The first report of $R$. (B.) microplus resistant to fipronil in Northern States of Mexico was made by Miller et al. (2013).

Rodríguez-Vivas et al. (2007) studied 217 field populations of $R$. (B.) microplus and determined the prevalence (measured by bioassays) of farms with resistance to SPs, OPs and amitraz in the southern Mexico, and they found that SP resistance such as deltamethrin, cypermethrin and flumethrin was one of the most serious problems in the Mexican tropics (from 66 to $96 \%$ farms showed resistance to SPs). Furthermore, Rodriguez-Vivas et al. (2006a) studied 98 field populations of $R$. (B.) microplus in Yucatan, Mexico and found that 63,61 and 59\% of those tick populations were resistant to flumethrin, deltamethrin and cypermethrin, respectively. The findings of $R$. (B.) microplus resistant to all three major classes of acaricides in Mexico underscore the seriousness of the resistance situation and the importance of having a resistance management strategy in Mexico.

\section{Resistance of Rhipicephalus (B.) microplus to Macrocyclic Lactones}

The first reports of tick resistance to MLs were made in Brazil. Martins and Furlong (2001) reported cross-resistant R. (B.) microplus to doramectin, ivermectin and moxidectin in a field trial. Klafke et al. (2006) reported a $R$. (B.) microplus population resistant to ivermectin in the State of Sao Paulo, Brazil. The evaluated population (Barra Alegre) showed a $\mathrm{LC}_{50}$ value significantly higher than the susceptible strain and a resistance ratio (RR) of 3.78 (3.57-4.12). Recently, Klafke et al. (2011) evaluated the applicability of laboratory bioassays to diagnose ivermectin resistance in $R$. (B.) microplus. Studying nine different populations of cattle tick from the states of São Paulo, Rio Grande do Sul and Mato Grosso do Sul, Brazil, the authors found that populations without previous exposure to ivermectin exhibited RR between 0.87 and 1.01 . However, populations previously exposed to ivermectin showed RR between 1.83 and 4.62 .

Klafke et al. (2010) used four selection methods to increase the $\mathrm{RR}$ to ivermectin of a Brazilian $R$. (B.) microplus strain. After ten generations, the RR increased from 1.37 to 8.06 . This work showed for the first time that it was possible to increase ivermectin resistance in $R$. (B.) microplus in laboratory conditions.

Castro-Janer et al. (2011) studied the susceptibility of $18 R$. (B.) microplus field populations from different Uruguayan counties to ivermectin by using the larval immersion test. Five tick populations presented a higher $\mathrm{RR}_{50}$ (1.35-1.98) compared with the susceptible tick reference strain
Table 2 shows the resistance ratio estimates at 50\% and 99\% for ivermectin resistance in $R$. (B.) microplus subjected to the larval immersion in two states of Mexico. Perez-Cogollo et al. (2010a) reported for the first time field populations of $R$. (B.) microplus resistant to ivermectin in Yucatan, Mexico. The authors studied three cattle farms (SFDO, SPN, LUADY). The LUADY $\left(\mathrm{RR}_{50}\right.$ 2.04 and 2.29, $\mathrm{RR}_{99}: 2.67$ and 3.55), SPN $\left(\mathrm{RR}_{50}: 3.55\right.$ and 3.68, $\mathrm{RR}_{99}: 8.19$ and 11.06) and SFDO $\left(\mathrm{RR}_{50}: 6.84\right.$ and 8.59, $\mathrm{RR}_{99}$ 54.17 and 87.86) ticks had significantly higher $\mathrm{LC}_{50} / \mathrm{LC}_{99}$ than the reference susceptible Deutch strain, demonstrating resistance in the field-collected populations. Furthermore, there was significant difference between $\mathrm{LC}_{50} / \mathrm{LC}_{99}$ of the SFDO, SPN and LUADY tick populations, which indicates not only the presence of resistant populations, but also different levels of resistance to ivermectin in the field populations studied. Furthermore, Perez-Cogollo et al. (2010b) conducted a survey to evaluate the resistance level of 30 field populations of $R$. (B.) microplus to ivermectin at cattle farms with history of MLs use in Yucatan, Mexico. The authors found that field populations of $R$. (B.) microplus demonstrated various levels of resistance to ivermectin. The top three resistant populations were CHPAT $\left(\mathrm{RR}_{50}=10.23, \mathrm{RR}_{99}=179.6\right)$, $\mathrm{SDGO}$ $\left(\mathrm{RR}_{50}=7.37, \mathrm{RR}_{99}=115.3\right)$ and $\mathrm{FND}\left(\mathrm{RR}_{50}=7.09, \mathrm{RR}_{50}=50.22\right)$ However, the level of ivermectin resistance in most tick samples from cattle farms in Yucatan, Mexico were relatively low.

Fernández-Salas et al. (2012a) determined the status of resistance or susceptibility to ivermectin in 53 populations of $R$. (B.) microplus collected in another state of Mexico (Veracruz). They found that 13 tick populations were susceptible to ivermectin, 18 had incipient resistance and 22 had significant resistance. $\mathrm{RR}_{50}$ of the susceptible tick populations varied from 0.59 to 1.07. The populations that showed the highest level of resistance were: ANTE $\left(\mathrm{RR}_{50}=8.21 ; \mathrm{RR}_{99}=46.0\right)$, PALO $\left(\mathrm{RR}_{50}=6.25\right.$; $\left.\mathrm{RR}_{99}=35.47\right)$, P.VIE $\left(\mathrm{RR}_{50}=5.89 ; \mathrm{RR}_{99}=180.3\right), \mathrm{AURO}$ $\left(\mathrm{RR}_{50}=5.36 ; \mathrm{RR}_{99}=13.82\right.$ and $\mathrm{CEDR}\left(\mathrm{RR}_{50}=4.11 ; \mathrm{RR}_{99}=26.47\right)$ As a significant finding of this study, it was identified that farms that used MLs $\geq 4$ times per year were more likely to develop $R$. (B.) microplus resistant to ivermectin ( $\mathrm{OR}=13.0 ; \mathrm{p}=0.0028)$. Recently, Fernández-Salas et al. (2012b) reported for the first time a $R$. (B.) microplus population in Mexico with different levels of resistance to OP, SP, Amitraz and ivermectin. The studied tick population showed a RR at $99 \%$ to ivermectin of 6.52-9.58.

At present, the molecular basis of resistance to MLs is not well understood. Insensitivity of the $\mathrm{GluCl}$ receptor, which prevents drug binding to its target site, has been associated with ivermectin resistance in some nematodes and arthropods (McCAVERA et al., 2009; KWON et al., 2010). In arthropods, MLs resistance is also

Table 2. Resistance ratio estimates at $50 \%$ and $99 \%$ for ivermectin resistance in Rhipicephalus (Boophilus) microplus subjected to larval immersion test in two states of Mexico.

\begin{tabular}{cccc}
\hline Mexican state & $\begin{array}{c}\text { Total number of studied } \\
\text { tick populations }\end{array}$ & $\begin{array}{c}\text { Farm name and resistance ratio of tick populations where } \\
\text { the highest level of resistance to ivermectin was reported }\end{array}$ & References \\
\hline Yucatan & 3 & SFDO $\left(\mathrm{RR}_{50}=6.84 \text { and } 8.59, \mathrm{RR}_{99}=54.17 \text { and } 87.86\right)^{*}$ & Perez-Cogollo et al. $(2010 \mathrm{a})$ \\
Yucatan & 30 & $\mathrm{CHPAT}\left(\mathrm{RR}_{50}=10.23, \mathrm{RR}_{99}=179.6\right)$ & Perez-Cogollo et al. $(2010 \mathrm{~b})$ \\
Veracruz & 53 & P.VIE $\left(\mathrm{RR}_{50}=5.89 ; \mathrm{RR}_{99}=180.3\right)$ & Fernández-Salas et al. $(2012 \mathrm{a})$ \\
Veracruz & 1 & $\mathrm{CLAR}\left(\mathrm{RR}_{50}=2.67 \text { and } 3.03, \mathrm{RR}_{99}=6.52 \text { and } 9.58\right)^{*}$ & Fernández-Salas et al. $(2012 \mathrm{~b})$ \\
\hline $\mathrm{RR}_{50}:$ resistance ratio at $50 \%, \mathrm{RR}_{99}:$ resistance ratio at $99 \% . *$ Bioassays were performed twice at different times with different collected samples
\end{tabular}


associated with an increase in oxidative metabolism. Recently, it has become evident from molecular, biochemical and pharmacokinetic studies that the most important molecules involved in all of these processes are ATP-binding cassette $(\mathrm{ABC})$ transporter proteins (BOURGUINAT et al., 2011). ABC transporters comprise a superfamily of membrane-integrated proteins expressed in all organisms, from bacteria to humans. These proteins are responsible for pumping xenobiotic and endogenous metabolites through extra- and intracellular membranes, thereby reducing cellular concentrations of toxic compounds (HOLLAND; BLIGHT, 1999). Recently, Pohl et al. (2011) demonstrated that the ABC transporter efflux pump is a defense mechanism against ivermectin in $R$. (B.) microplus.

The use of MLs to control ticks and gastrointestinal in cattle is expected to continue to increase in Mexico, due to convenience (broad spectrum), increasingly accessible prices (especially generic versions of MLs) and lack of effective chemical alternatives. A better understanding on spatial distribution, risk factors and possible cross-resistance associated to ivermectin resistance in the Mexican tropics is needed (PEREZ-COGOLLO et al., 2010a). Strategies of resistance management need to be pointed to keep the selection pressure at a minimum level, while still achieving an appropriate control of the parasite. Strategies involving the early detection of resistance and use of tactics designated to increase the useful life of MLs are recommended.

\section{Conclusions}

In Mexico many field populations of $R$. (B.) microplus are resistant to multiple classes of antiparasitic drugs, including OPs, SPs, amitraz and ivermectin. Ivermectin-resistant populations of $R$. (B.) microplus have been reported in Latin America, especially in Mexico (in two states, Veracruz and Yucatan). Although ivermectin resistance levels in $R$. (B.) microplus from Mexico were generally low in most cases, some field populations of $R$. (B.) microplus exhibited high levels of ivermectin resistance. Strategies involving the early detection of resistance and the use of integrated tick control are recommended.

\section{References}

Aguilar-Tipacamu G, Rodriguez-Vivas RI. Effect of moxidectin against natural infestation of the cattle tick Boophilus microplus (Acarina: Ixodidae) in the Mexican tropics. Vet Parasitol 2003; 111(2-3): 211-216. http://dx.doi.org/10.1016/S0304-4017(02)00355-2

Arieta-Román RJ, Rodríguez-Vivas RI, Rosado-Aguilar JA, RamírezCruz GT, Basto-Estrella G. Persistencia de la eficacia de dos lactonas macrocíclicas contra infestaciones naturales de Rhipicephalus (Boophilus) microplus en bovinos del trópico mexicano. Rev Mex Cienc Pecu 2010; 1(1): 59-67.

Barré N, Li AY, Miller RJ, Gaia H, Delathiére JM, Davey RB, et al. In vitro and in vivo evaluation of deltamethrin and amitraz mixtures for the control of Rhipicephalus (Boophilus) microplus (Acari: Ixodidae) in New Caledonia. Vet Parasitol 2008; 155(1-2): 110-119. PMid:18565679. http://dx.doi.org/10.1016/j.vetpar.2008.04.016
Bourguinat C, Keller K, Blagburn B, Schenker R, Geary TG, Prichard RK. Correlation between loss of efficacy of macrocyclic lactone heartworm anthelmintics and P-glycoprotein genotype. Vet Parasitol 2011; 176(4): 374-381. PMid:21300438. http://dx.doi. org/10.1016/j.vetpar.2011.01.024

Casida JE, Gammon DW, Glickman AH, Lawrence LJ. Mechanisms of selective action of pyrethroid insecticides. Ann Rev Pharmacol Toxicol 1983; 23: 413-438. PMid:6347050. http://dx.doi.org/10.1146/ annurev.pa.23.040183.002213

Castro-Janer E, Rifran L, González P, Niell C, Piaggio J, Gil A, et al. Determination of the susceptibility of Rhipicephalus (Boophilus) microplus (Acari: Ixodidae) to ivermectin and fipronil by Larval Immersion Test (LIT) in Uruguay. Vet Parasitol 2011; 178(1-2): 148155. PMid:21277092. http://dx.doi.org/10.1016/j.vetpar.2010.12.035

Catterall WA. Structural biology: a 3D view of sodium channels. Nature 2001; 409(6823): 988-991. PMid:11234048. http://dx.doi. org/10.1038/35059188

Cole LM, Nicholson RA, Casida JE. Action of phenylpyrazole insecticides at the GABA-gated Chloride channel. Pestic Biochem Physiol 1993; 46(1): 47-54. http://dx.doi.org/10.1006/pest.1993.1035

Corbett JR. Insecticides inhibiting acetylcholinesterase. In: Corbett JR. The biochemical mode of action of pesticides. New York: Academic Press; 1974 a.

Corbett JR. Neuroactive insecticides, excluding inhibitors of acetylcholinesterase. In: Corbett JR. The biochemical mode of action of pesticides. New York: Academic Press; $1974 \mathrm{~b}$.

Davey RB, Ahrens EH, George JE, Hunter JS, Jeannin P. Therapeutic and persistent efficacy of fipronil against Boophilus microplus (Acari: Ixodidae) on cattle. Vet Parasitol 1998; 74(2-4): 261-276. http://dx.doi. org/10.1016/S0304-4017(97)00152-0

Davey RB, Miller JA, George JE, Snyder DE. Effect of repeated spinosad treatments on cattle against Boophilus annulatus under south Texas field conditions. Southwest Entomol 2005; 30(4): 245-255.

Diersmann E, Ferreira L, Chaaban A, Moya-Borja G. Impacto do uso de ivermectina de longa ação na sucessão ecológica dos excrementos de bovinos tratados, tomando-se como modelo o besouro coprófago Digitonthophagus gazella (Fabricius, 1787). Rev Bras Agroecol 2006; 1: 883-886.

Dong K. Insect sodium channels and insecticide resistance. Invert Neurosci 2007; 7(1): 17-30. PMid:17206406 PMCid:PMC3052376. http://dx.doi.org/10.1007/s10158-006-0036-9

Evans PD, Gee JD. Action of formamidine pesticides on octopamine receptors. Nature 1980; 287(5777): 60-62. http://dx.doi. org/10.1038/287060a0

Fernández-Salas A, Rodríguez-Vivas RI, Alonso-Díaz MA, BasurtoCamberos H. Ivermectin resistance status and factors associated in Rhipicephalus microplus (Acari: Ixodidae) populations from Veracruz, Mexico. Vet Parasitol2012a; 190(1-2): 210-215. PMid:22785128. http:// dx.doi.org/10.1016/j.vetpar.2012.06.003

Fernández-Salas A, Rodríguez-Vivas RI, Alonso-Díaz MA. First report of a Rhipicephalus microplus tick population multi-resistant to acaricides and ivermectin in the Mexican tropics. Vet Parasitol 2012b; 186(3-4): 338342. PMid:21824728. http://dx.doi.org/10.1016/j.vetpar.2011.07.028

Fragoso-Sanchez H, Garcia-Vazquez Z, Tapia-Perez G, Ortiz-Najera A, Rosario-Cruz R, Rodriguez-Vivas RI. Response of Mexican Riphicephalus 
(Boophilus) microplus ticks to selection by amitraz and genetic analysis of attained resistance. J Entomol 2011; 8(3): 1812-5670.

George JE, Pound JM, Davey RB. Chemical control of ticks on cattle and the resistance of these parasites to acaricides. Parasitology 2004; 129(Suppl S1): S353-S366. PMid:15938518. http://dx.doi.org/10.1017/ S0031182003004682

Hempel H, Scheffczyk A, Schallnass HJ, Lumaret JP, Alvinerie M, Römbke J. Toxicity of four veterinary parasiticides on larvae of the dung beetle Aphodius constans in the laboratory. Environ Toxicol Chem 2006; 25(12): 3155-3163. PMid:17220084. http://dx.doi. org/10.1897/06-022R2.1

Holland IB, Blight MA. ABC-ATPases, adaptable energy generators fuelling transmembrane movement of a variety of molecules in organisms from bacteria to humans. J Mol Biol 1999; 293(2): 381-399. PMid:10529352. http://dx.doi.org/10.1006/jmbi.1999.2993

Insecticide Resistance Action Committee - IRAC. IRAC International Insecticide Mixture Statement. Version 1.0. [online]. 2012. [cited 2014 Feb 05]. Available from: http://www.irac-online.org/content/uploads/ IRAC_Mixture_Statement_v1.0_10Sept12.pdf.

Jonsson NN, Hope M. Progress in the epidemiology and diagnosis of amitraz resistance in the cattle tick Boophilus microplus. Vet Parasitol 2007; 146(3-4): 193-198. PMid:17448604. http://dx.doi. org/10.1016/j.vetpar.2007.03.006

Jonsson NN, Mayer DG, Matschoss AL, Green PE, Ansell J. Production effects of cattle tick (Boophilus microplus) infestation of high yielding dairy cows. Vet Parasitol 1998; 78: 65-77. http://dx.doi.org/10.1016/ S0304-4017(98)00118-6

Kirst HA. The spinosyn family of insecticides: realizing the potential of natural products research. J Antibiot 2010; 63(3): 101-111. PMid:20150928. http://dx.doi.org/10.1038/ja.2010.5

Kiss T, Cadar D, Spînu M. Tick prevention at a crossroad: new and renewed solutions. Vet Parasitol 2012; 187(3-4): 357-366. PMid:22424918. http://dx.doi.org/10.1016/j.vetpar.2012.02.010

Klafke GM, Sabatini G, Albuquerque T, Martins JR, Kemp D, Miller $\mathrm{RJ}$, et al. Larval immersion tests with ivermectin populations of the cattle tick Rhipicephalus (Boophilus) microplus (Acari: Ixodidae) from State of Sao Paulo, Brazil. Vet Parasitol 2006; 142(3-4): 386-390. PMid:16904265. http://dx.doi.org/10.1016/j.vetpar.2006.07.001

Klafke GM, Albuquerque TA, Miller RJ, Schumaker TT. Selection of an ivermectin-resistant strain of Rhipicephalus microplus (Acari: Ixodidae) in Brazil. Vet Parasitol 2010; 168(1-2): 97-104. PMid:19864067. http:// dx.doi.org/10.1016/j.vetpar.2009.10.003

Klafke GM, Castro-Janer E, Mendes MC, Namindome A, Schumaker TT. Applicability of in vitro bioassays for the diagnosis of ivermectin resistance in Rhipicephalus microplus (Acari: Ixodidae). Vet Parasitol 2011; 184(2-4): 212-220. PMid:21978742. http://dx.doi. org/10.1016/j.vetpar.2011.09.018

Knowles CO. Structure-activity relationships among amidine acaricides and insecticides. In: Coats JR. Insecticide mode of action. Academic: New York; 1982. p. 243-277. PMid:6172481. http://dx.doi.org/10.1016/ B978-0-12-177120-1.50014-X

Kwon DH, Yoon KS, Clark JM, Lee SH. A point mutation in a glutamategated chloride channel confers abamectin resistance in the two-spotted spider mite, Tetranychus urticae Koch. Insect Mol Biol 2010; 19(4): $583-$ 591. PMid:20522121.
Kwong TC. Organophosphate pesticides: biochemistry and clinica toxicology. Ther Drug Monit 2002; 24(1): 144-149. PMid:11805735. http://dx.doi.org/10.1097/00007691-200202000-00022

Lanusse C, Lifschitz A, Virkel G, Alvarez L, Sánchez S, Sutra JF, et al. Comparative plasma disposition kinetics of ivermectin, moxidectin and doramectin in cattle. J Vet Pharmacol Ther 1997; 20(2): 91-99. PMid:9131534. http://dx.doi.org/10.1046/j.1365-2885.1997.00825.x

Lewer P, Hahn DR, Karr LL, Duebelbeis DO, Gilbert JR, Crouse GD, et al. Discovery of the butenyl-spinosyn insecticides: novel macrolides from the new bacterial strain Saccharopolyspora pogona. Bioorg Med Chem 2009; 17(12): 4185-4196. PMid:19324553. http://dx.doi. org/10.1016/j.bmc.2009.02.035

Li AY, Chen AC, Miller RJ, Davey RB, George JE. Acaricide resistance and synergism between permethrin and amitraz against susceptible and resistant strains of Boophilus microplus (Acari: Ixodidae). Pest Manag Sci 2007; 63(9): 882-889. PMid:17665370. http://dx.doi.org/10.1002/ ps. 1417

Lifschitz A, Virkel G, Imperiale F, Pis A, Lanusse C. Fármacos endectocidas: avermectinas y milbemicinas. In: Botana López LM, Landoni MF, Martín-Jiménez T. Farmacología y terapéutica veterinaria. Madrid: McGraw-Hill-Interamericana; 2002. p. 545-558.

Lin H, Chuan-hua X, Jin-jun W, Ming L, Wen-cai L, Zhi-mo $Z$. Resistance selection and biochemical mechanism of resistance to two acaricides in Tetranychus cinnabarinus (Boiduval). Pestic Biochem Physiol 2009; 93(1): 47-52. http://dx.doi.org/10.1016/j. pestbp.2008.11.001

Liu MY, Plapp FW. Formamidines as synergists of cypermethrin in susceptible and pyrethroid resistant house flies (Diptera: Muscidae). J Econ Entomol 1990; 83(6): 2181-2186. PMid:2280046.

Lumaret JP, Errouissi F, Floate K, Römbke J, Wardhaugh K. A review on the toxicity and non-target effects of macrocyclic lactones in terrestrial and aquatic environments. Curr Pharm Biotechnol 2012; 13(6): 10041060. PMid:22039795 PMCid:PMC3409360. http://dx.doi. org/10.2174/138920112800399257

MacDonald JM. Flea control: an overview of treatment concepts for North America. Vet Dermatol 1995; 6(3): 121-130. http://dx.doi. org/10.1111/j.1365-3164.1995.tb00055.x

Martin RJ, Robertson AP, Wolstenholme AJ. Mode of action of the macrocyclic lactones. In: Vercruysse J, Rew RS, editors. Macrocyclic Lactones in Antiparasitic Therapy. Wallingford: CABI Publishing; 2002. p. 125-140. http://dx.doi.org/10.1079/9780851996172.0125

Martins J, Furlong J. Avermectin resistance of the cattle tick Boophilus microplus in Brazil. Vet Rec 2001; 149(2): 64. PMid:11488352.

Mendes MC, Lima CK, Nogueira AH, Yoshihara E, Chiebao DP, Gabriel FH, et al. Resistance to cypermethrin, deltamethrin and chlorpyriphos in populations of Rhipicephalus (Boophilus) microplus (Acari: Ixodidae) from small farms of the State of São Paulo, Brazil. Vet Parasitol 2011; 178(3-4): 383-388. PMid:21306827. http://dx.doi. org/10.1016/j.vetpar.2011.01.006

McCavera S, Rogers AT, Yates DM, Woods DJ, Wolstenholme AJ. An ivermectin-sensitive glutamate-gated chloride channel from the parasitic nematode Haemonchus contortus. Mol Pharmacol 2009; 75(6): $1347-$ 1355. PMid:19336526 PMCid:PMC2684884. http://dx.doi. org/10.1124/mol.108.053363

Miller RJ, Almazán C, Ortíz-Estrada M, Davey RB, GeorgeJE, Pérez de León A. First report of fipronil resistance in Rhipicephalus (Boophilus) microplus 
of Mexico. Vet Parasitol2013; 191(1-2): 97-101. PMid:23026557. http:// dx.doi.org/10.1016/j.vetpar.2012.08.011

Narahashi T. Toxins that modulate the sodium channel gating mechanism. In: Kao CY, Levinson SR, editors. Annals of the New York Academy of Sciences: tetrodotoxin, saxitoxin and the molecular biology of the sodium channel. New York: The New York Academy of Sciences; 1986. p. 133151. PMid:2433987.

Nari-Henrioud A. Towards sustainable parasite control practices in livestock production with emphasis in Latin America. Vet Parasitol 2011; 180(1-2): 2-11. PMid:21723040. http://dx.doi. org/10.1016/j.vetpar.2011.05.026

Organisation for Economic Co-operation and Development - OECD. Guidance document on the determination of the toxicity of a test chemical to the dung beetle Aphodius constans. Environment, Health and Safety Publications, Series on Testing and Assessment [online]. 2010. Available from: http://search.oecd.org/officialdocuments/ displaydocumentpdf/?cote $=$ env $/ j m / m o n o(2010) 13 \&$ doclanguage $=e n$

Oliveira PR, Bechara GH, Morales MAM, Camargo-Mathias MI. Action of the chemical agent fipronil on the reproductive process of semiengorged females of the tick Rhipicephalus sanguineus (Latreille, 1806) (Acari: Ixodidae): ultrastructural evaluation of ovary cells. Food Chem Toxicol 2009; 47(6): 1255-1264. PMid:19250957. http://dx.doi. org/10.1016/j.fct.2009.02.019

Ómura S. Ivermectin: 25 years and still going strong. Int J Antimicrob Agents 2008; 31(2): 91-98. PMid:18037274. http://dx.doi.org/10.1016/j. ijantimicag.2007.08.023

Orr GL, Orr N, Cornfield L, Gole JWD, Downer RGH. Interaction of formamidine pesticides with insect neural octopamine receptors: effects of radioligand binding and cyclic AMP production. Pestic Sci 1990; 30(3): 285-294. http://dx.doi.org/10.1002/ps.2780300305

Orr N, Shaffner AJ, Richey K, Crouse GD. Novel mode of action of spinosad: Receptor binding studies demonstrating lack of interaction with known insecticidal target sites. Pestic Biochem Physiol 2009; 95(1): 1-5. http://dx.doi.org/10.1016/j.pestbp.2009.04.009

Pegram RG, Tatchell RJ, de Castro J, Chizyuka HGB, Creek MJ, McCosker PJ, et al. Tick control: new concepts. World Animal Rev 1993; 74-75: 2-11.

Perez-Cogollo LC, Rodriguez-Vivas RI, Ramirez-Cruz GT, Miller RJ. First report of the cattle tick Rhipicephalus microplus resistant to ivermectin in Mexico. Vet Parasitol 2010a; 168(1-2): 165-169. PMid:19951828. http://dx.doi.org/10.1016/j.vetpar.2009.10.021

Perez-Cogollo LC, Rodriguez-Vivas RI, Ramirez-Cruz GT, RosadoAguilar JA. Survey of Rhipicephalus microplus resistance to ivermectin at cattle farms with history of macrocyclic lactones use in Yucatan, Mexico. Vet Parasitol2010b; 172(1-2): 109-113. PMid:20570047. http://dx.doi. org/10.1016/j.vetpar.2010.04.030

Pohl PC, Klafke GM, Carvalho DD, Martins JR, Daffre S, Silva Vaz Jr, et al. ABC transporter efflux pumps: A defense mechanism against ivermectin in Rhipicephalus (Boophilus) microplus. Int J Parasitol 2011; 41(13-14): 1323-1333. PMid:22036897. http://dx.doi. org/10.1016/j.ijpara.2011.08.004

Prullage JB, Cawthorne WG, Le Hir de Fallois LP, Timmons PR. Synergy between fipronil and amitraz in a Rhipicephalus sanguineus tick residual contact test. Exp Appl Acarol 2011; 54(2): 173-176. PMid:21243407. http://dx.doi.org/10.1007/s10493-011-9424-x
Rauh JJ, Lummis SCR, Sattelle DB. Pharmacological and biochemical properties of insect GABA receptors. Trends Pharmacol Sci 1990; 11(8): 325-329. http://dx.doi.org/10.1016/01656147(90)90236-2

Raymond-Delpech V, Matsuda K, Sattelle BM, Rauh JJ, Sattelle DB. Ion channels: molecular targets of neuroactive insecticides. Invert Neurosci 2005; 5(3-4): 119-133. PMid:16172884. http://dx.doi. org/10.1007/s10158-005-0004-9

Rock DW, DeLay RL, Gliddon MJ. Moxidectin. In: Vercruysse J, Rew RS, editors. Macrocyclic lactones in antiparasitic therapy. Wallingford: CAB International; 2002. p. 75- 96. http://dx.doi. org/10.1079/9780851996172.0075

Rodríguez-Vivas RI, Mata MY, Pérez GE, Wagner G. The effect of management factors on the seroprevalence of Anaplasma marginale in Bos indicus cattle in the Mexican tropics. Trop Anim Health Prod 2004; 36(2): 135-143. PMid:14998312. http://dx.doi.org/10.1023/ B:TROP.0000012105.19518.80

Rodríguez-Vivas RI, Quiñones AF, Fragoso SH. Epidemiología y control de la garrapata Boophilus en México. In: Rodríguez-Vivas RI. Enfermedades de importancia económica en producción animal. México: McGraw-Hill; 2005. p. 571-592.

Rodríguez-Vivas RI, Alonso-Díaz MA, Rodríguez-Arevalo F, FragosoSanchez H, Santamaria VM, Rosario-Cruz R. Prevalence and potential risk factors for organophosphate and pyrethroid resistance in Boophilus microplus ticks on cattle ranches from the state of Yucatan, Mexico. Vet Parasitol 2006a; 136(3-4): 335-442. PMid:16413971. http://dx.doi. org/10.1016/j.vetpar.2005.05.069

Rodríguez-Vivas RI, Rodriguez-Arevalo F, Alonso-Díaz MA, FragosoSanchez H, Santamaria VM, Rosario-Cruz R. Prevalence and potential risk factors for amitraz resistance in Boophilus microplus ticks in cattle farms from the state of Yucatan, Mexico. Prev Vet Med 2006b; 75(3-4): 280-286. PMid:16730819. http://dx.doi.org/10.1016/j.prevetmed.2006.04.001

Rodríguez-Vivas RI, Rivas AL, Chowell G, Fragoso SH, Rosario CR, García Z, et al. Spatial distribution of acaricide profiles (Boophilus microplus strains susceptible or resistant to acaricides) in southeastern Mexico. Vet Parasitol2007; 146(1-2): 158-169. PMid:17349747. http:// dx.doi.org/10.1016/j.vetpar.2007.01.016

Rodríguez-Vivas RI, Arieta-Román JR, Perez-Cogollo LC, RosadoAguilar JA, Ramírez-Cruz GT, Basto-Estrella G. Uso de lactonas macrocíclicas para el control de la garrapata Rhipicephalus (Boophilus) microplus en el ganado bovino. Arch Med Vet 2010; 42(3): 115-123. http://dx.doi.org/10.4067/S0301-732X2010000300002

Rodríguez-Vivas RI, Hodgkinson JE, Trees AJ. Resistencia a los acaricidas en Rhipicephalus (Boophilus) microplus: situación actual y mecanismos de resistencia. Rev Mex Cienc Pecu 2012; 3(S1): 9-24.

Rodríguez-Vivas RI, Li AY, Ojeda-Chi MM, Trinidad-Martinez I, Rosado-Aguilar JA, Miller RJ, et al. In vitro and in vivo evaluation of cypermethrin, amitraz, and piperonyl butoxide mixtures for the control of resistant Rhipicephalus (Boophilus) microplus (Acari: Ixodidae) in the Mexican tropics. Vet Parasitol2013; 197(1-2): 288-296. PMid:23948559. http://dx.doi.org/10.1016/j.vetpar.2013.07.018

Rodríguez-Vivas RI, Miller RJ, Ojeda-Chi MM, Rosado-Aguilar JA, Trinidad-Martínez IC, Pérez de León AA. Acaricide and ivermectin resistance in a field population of Rhipicephalus microplus (Acari: Ixodidae) collected from red deer (Cervus elaphus) in the Mexican tropics. Vet Parasitol 2014; 200(1-2): 179-188. PMid:24365245. http://dx.doi. org/10.1016/j.vetpar.2013.11.025 
Schnitzerling HJ, Nolan J, Hughes S. Toxicology and metabolism of some synthetic pyrethroids in larvae of susceptible and resistant strains of the cattle tick Boophilus microplus (Can). Pest Sci 1983; 14(1): 64-72. http://dx.doi.org/10.1002/ps.2780140110

Seebeck RM, Springell PH, O'Kelly JC. Alterations in host metabolism by the specific and anorectic effects of the cattle tick (Boophilus microplus). I. food intake and body weight growth. Aust J Biol Sci 1971; 24(2): 373380. PMid:5280977.

Shoop WL, Mrozik KH, Fisher MH. Structure and activity of avermectins and milbemycins in animal health. Vet Parasitol 1995; 59(2): 139-156. http://dx.doi.org/10.1016/0304-4017(94)00743-V

Sibson GJ. The effects of moxidectin against natural infestation of cattle tick (Boophilus microplus). Aust Vet J 1994; 71(11): 381-382. PMid:7726764. http://dx.doi.org/10.1111/j.1751-0813.1994. tb00935.x

Sindicato Nacional da Indústria de Produtos para Saúde Animal - SINDAN. São Paulo: SINDAN; 2013. Available from: http:// www.sindan.org.br.

Soberanes NC, Santamaría MV, Fragoso HS, García VZ. First case reported of amitraz resistance in the cattle tick Boophilus microplus in Mexico. Téc Pec Méx 2002; 40(1): 81-92.

Soderlund DM, Clark JM, Sheets LP, Mullin LS, Piccirillo VJ, Sargent $\mathrm{D}$, et al. Mechanisms of pyrethroid neurotoxicity: implications for cumulative risk assessment. Toxicology 2002; 171(1): 3-59. http://dx.doi. org/10.1016/S0300-483X(01)00569-8

Solorio-Rivera JL, Rodríguez-Vivas RI, Pérez-Gutierrez E, Wagner G. Management factors associated with Babesia bovis seroprevalence in cattle from eastern Yucatán, Mexico. Prev Vet Med 1999; 40(3-4): 261-269. http://dx.doi.org/10.1016/S0167-5877(99)00019-7

Spindler KD, Spindler-Barth M, Londershausen M. Chitin metabolism: a target for drugs against parasites. Parasitol Res 1990; 76(4): 283-8. http://dx.doi.org/10.1007/BF00928180

Stendel W. Experimental studies of the tickicidal effect of Bayticol ${ }^{\circ}$ Pour-on. Vet Med Rev 1985; 2: 99-111.
Suárez V, Lifschitz A, Sallovitz J, Lanusse C. Effects of faecal residues of moxidectin and doramectin on the activity of arthropods in cattle dung. Ecotoxicol Environ Saf2009; 72(5): 1551-1558. PMid:18192015. http:// dx.doi.org/10.1016/j.ecoenv.2007.11.009

Sutherst RW, Maywald GF, Kerr JD, Stegeman DA. The effect of cattle tick (Boophilus microplus) on the growth of Bos indicus $\mathrm{x}$ Bos taurus steers. Aust J Agr Res 1983; 34(3): 317-327. http://dx.doi.org/10.1071/ AR9830317

Tan J, Liu Z, Tsai TD, Valles SM, Goldin AL, Dong K. Novel sodium channel gene mutations in Blattella germanica reduce the sensitivity of expressed channels to deltamethrin. Insect Biochem Mol Biol 2002; 32(4): 445-454. http://dx.doi.org/10.1016/S09651748(01)00122-9

Taylor MA. Recent developments in ectoparasiticides. Vet J2001; 161(3): 253-268. PMid:11352483. http://dx.doi.org/10.1053/ tvjl.2000.0549

Trapapa BJ. The campaign against Boophilus microplus in Mexico, benefit, problems and prospects. In: Garcia-Vasquez Z. Animal production and health. Mexico: FAO; 1989. p. 50-75.

Turner MJ, Schaeffer JM. Mode of action of ivermectin. In: Campbell WC. Ivermectin and Abamectin. New York: Springer-Verlag; 1989. p. $73-$ 78. PMid:2714981. http://dx.doi.org/10.1007/978-1-4612-3626-9_5

White N, Sutherst RW, Hall N, Wish-Wilson P. The vulnerability of the Australian beef industry to impacts of the cattle tick (Boophilus microplus) under climate change. Climatic Change 2003; 61(1-2): 157-190. http:// dx.doi.org/10.1023/A:1026354712890

Zhao Y, Park Y, Adams ME. Functional and evolutionary consequences of pyrethroid resistance mutations in $S 6$ transmembrane segments of a voltagegated sodium channel. Biochem Biophys Res Commun 2000; 278(3): 516521. PMid:11095943. http://dx.doi.org/10.1006/bbrc.2000.3832

Zhao X, Yeh JZ, Salgado VL, Narahashi T. Sulfone metabolite of fipronil blocks gamma-aminobutyric acid- and glutamate-activated chloride channels in mammalian and insect neurons. J Pharmacol Exp Ther 2005; 314(1): 363-373. PMid:15701711. http://dx.doi. org/10.1124/jpet.104.077891 